\title{
„A CÉL AZ, hOgY SEgítsüK a HALlgatókAT aZ INFORMációs FORRÁSOK KÖZÖTTI ELIGAZODÁSBAN, AZ INFORMÁCIÓ TUDATOS ÉS ETIKUS FELHASZNÁLÁSÁBAN, AZ ÖNÁLLÓ MUNKÁBAN." INTERJú Nagy Zsuzsannával, a Budapesti CoRvinus EGYETEM KöNYVTÁRÁNAK FÖIGAZGATÓJÁVAL ${ }^{1}$ INTERVIEW WITH ZsUZSANNA NAGY, DIRECTOR OF THE LibraRY OF THE CORVINUS UNIVERSITY OF BUDAPEST
}

\begin{abstract}
A Köz-gazdaság folyóirat Nagy Zsuzsannát a Budapesti Corvinus Egyetem Könyvtárának föigazgatóját kérdezte, a könyvtár szerepéröl a kutatói kultúra megteremtésében, az átalakuló disszeminációs csatornákról, a hallgatókkal való kapcsolattartásról és a lehetséges kihívásokról.
\end{abstract}

The Review of Economic Theory and Policy asked Zsuzsanna Nagy, Director of the Corvinus University of Budapest, about the role of the library in creating a research culture, about changing dissemination channels, engaging possibilities with students, and about potential challenges.

Trautmann László: Az elmúlt néhány évben a Budapesti Corvinus Egyetemen már komoly erőfeszítések történtek a kutatásorientáltság megerősítése érdekében. Ennek milyen hatásai voltak az egyetem központi könyvtárának szervezetére és költségvetésére? A beszerzések területén milyen előrelépések történtek, és hol van ebből a szempontból a legnagyobb elmaradás?

Nagy Zsuzsanna: A kérdés részben a könyvtár szervezetére vonatkozik, ezért el kell mondanom, hogy 2017 januárja óta nem Központi, hanem Egyetemi Könyvtár a hivatalos nevünk. Ennek azért van jelentősége, mert az egyetem egyetlen könyvtárat müködtet az oktatás és kutatás kiszolgálására, idén szeptembertől immár két - budapesti és székesfehérvári - telephellyel. A könyvtári szervezeten belül így nincs széttagoltság, amit én ésszerü és hatékony megoldásnak tartok. A kérdés lényegére válaszolva: a könyvtári szolgáltatások és a szervezet is átalakult, hogy az egyetem kutatási orientációját még jobban támogassa. Létrehoztuk az Oktatás- és Kutatástámogató Osztályt, mint belső szervezeti egységet. Ennek fö feladata az egyetemen folyó kutatási és publikációs tevékenység támogatása olyan szolgáltatások révén, mint a kutatási eredmények megőrzését és disszeminációját szolgáló elektronikus gyüjtemények müködtetése, az egyetemi tartalomkezelés koordinálása, az oktatói publikációk nyilvántartásának és az éppen aktuálisan elöírt központi adatbázisba feltöltésének segítése, bibliometriai és publikációs tanácsadás, stb.

A szakirodalom és egyéb, oktatást és kutatást támogató adatforrások beszerzésére fordítható pénzügyi keretek az elmúlt 3-4 évben jelentősen nőttek. A 2012-2013-ban megtapasztalt pénztelenség után ma már elmondhatjuk, hogy az egyetemi polgárok általános szakirodalmi igényeit jó szinten

${ }^{1}$ DOI: $10.14267 /$ RETP2019.04.06 
ki tudjuk elégíteni. Jelentős segítséget ad ebben az egyre eredményesebben működő EISZ nemzeti program, ami részben központi költségvetési forrásból, részben az egyetemek, tagintézmények által befizetett önrészekből országos konzorciumi formában szerzi be a tudományos kutatás számára legfontosabb elektronikus információforrásokat. A Budapesti Corvinus Egyetemen jelenleg elérhetők a legnagyobb tudományos kiadók folyóiratcsomagjai (Elsevier, Emerald, Sage, SpringerNature, Taylor \& Francis, Wiley), az OECD elektronikus könyvtára, több statisztikai-üzleti adatbázis (MarketLine, Statista, EMIS Hungary, IMF eLibrary) és sok egyéb forrás. Amikor tudományos információs forrásokról beszélünk, akkor magától értetődően elektronikus forrásokra gondolunk. Kivételt képeznek a társadalom- és humán tudományok terén továbbra is fontos nyomtatott monográfiák. Talán itt beszélhetünk némi elmaradásról az angol nyelvü szakirodalom tekintetében. Ennek több oka van, ezek közül csak az egyik a 2000-es évek elejétől 2013-14-ig tartó kényszerü takarékoskodás. Legalább ilyen fontos, hogy nem vagy csak korlátozott mértékben jutnak el hozzánk az oktatói-kutatói igények, illetve sokan nem tartják természetesnek azt, hogy az egyetemi, egyetemi pályázati forrásokból vásárolt könyvek a könyvtárba kerülnek. Számos lehetőséget ajánlunk az oktatói közösségnek igényeik bejelentésére. Legújabb kezdeményezésünk a felhasználó által indukált beszerzés modellje (DDA - demand driven acquisition) az e-könyvek terén. Megfontolandó, hogy átgondoljuk a könyvbeszerzés jelenlegi egyetemi mechanizmusát.

Trautmann László: Az egyetemi közéletben gyakran felmerül a kutatói kultúra megteremtésének igénye, a felzárkózás az európai élvonalhoz? Ezt hogyan tudja segíteni a könyvtár? Mit igényel a könyvtártól a gazdálkodástudományi, közgazdaság-tudományi és társadalomtudományi kutatásokhoz az egyetem oktatói és kutatói közössége, és a könyvtár ezeket az igényeket mennyiben tudja kielégíteni? Hol van a legnagyobb elmaradás az igények és a kínált szolgáltatások terïletén?

Nagy Zsuzsanna: Egy általános megjegyzés: a kutatói kultúra összetett dolog, és tapasztalatom szerint lassan, leginkább generációváltás vagy egyéb jelentős személyi változások révén változik. Kettébontanám a tényleges kérdést. Egyrészt a kutatáshoz szükséges forrásokra, másrészt a könyvtári szolgáltatásokra. Az előző részben általánosságban beszéltem a szakirodalmi és információs igényekről, ehhez képest a kutatóknak, kutatócsoportoknak időnként olyan speciális üzleti, pénzügyi adathalmazokra, adatsorokra van szükségük, amiket az általános előfizetések nem fednek le, és az egyetemi közösség nagy részének nincs is rá szüksége. Itt látok, ha nem is elmaradást, de kielégítetlen igényeket. Ezekröl már elkezdtünk beszélgetni a kutatói közösség egyes tagjaival, ezt az együtt gondolkodást mindenképpen folytatni szükséges. A könyvtárnak azért célszerű az ilyen igények kielégítésében közreműködnie, hogy egyetemi szinten összehangoltan biztosítsuk a kutatók munkájához szükséges forrásokat. A kutatásokat támogató könyvtári szolgáltatások terén nem látok elmaradást. Talán a kommunikációt lehetne javítani, hogy a kutatói közösség tájékozottabb legyen a könyvtár szolgáltatásairól, például a cikkek nyílt hozzáférésű megjelenését támogató, egyes nagy kiadókkal kötött ún. „read and publish” megállapodásokról, a repozitóriumi közzététel előnyeiről, a könyvtár kiadványmenedzsment szolgáltatásáról, stb. A hatásosabb kommunikáció persze nem csak a könyvtáron múlik.

Trautmann László: Az egyetem oktatói és kutatói által készített tanulmányok, könyvek diszszeminálását hogyan, milyen eszközökkel tudja segíteni a könyvtár? Hogyan lehetne javítani ezen a folyamaton, ha szükséges? 
Nagy Zsuzsanna: A könyvtár által müködtetett repozitóriumok a disszemináció hatékony eszközei, mivel a világszerte használt általános és tudományos keresőmotorok (Google, Google Scholar, Base, EconBiz, Core) indexelik, így kereshetővé teszik a tartalmukat. A használati statisztikák igen kedvezőek. A Corvinus Kutatások esetében összesen 1,5 millió letöltés történt, csupán az elmúlt évben 360.000, ennek majdnem kétharmada külföldről . A Corvinus Kutatások az MTMT által minősített repozitórium. A repozitóriumba való feltöltéssel teljesíthető az Európai Unió (OpenAIRE), az OTKA, az NKFIH és más kutatásfinanszírozók által elvárt open access közzétételi kötelezettség.

A publikációk láthatósága, hatása, idézettsége nagymértékben függ a közzétételi csatornától. A könyvtár készséggel segít, különösen doktoranduszoknak, pályájuk elején járó kutatóknak a megfelelő folyóiratok, platformok kiválasztásában, különösen az ún, predátor vagy legalábbis kétes presztízsủ kiadók elkerülésében.

Trautmann László: A mai európai egyetemi kultúrának egyre szervesebb része, hogy a hallgatók bekapcsolódnak a kutatásokba, a hallgatók szakmai önállóságának fontos része a könyvtár használata, a szakirodalom önálló feldolgozása. Mi a tapasztalata, hol tartanak ebben a BCE hallgatói? Milyen kérésekkel fordulnak a könyvtárban dolgozó kollégákhoz, mennyire önállóak a szakirodalom keresésében?

Nagy Zsuzsanna: A kép vegyes. Sok motivált, egyetemi tanulmányaik és a szemináriumi munka eredményeképpen már a szakirodalomban, kutatásmódszertanban is eligazodni képes hallgatóval találkozunk. Ez főképpen a doktoranduszokra és a mesterképzésben részt vevőkre vonatkozik. Vannak azonban, nem kevesen, akik a szakdolgozat leadása elött néhány héttel elöször járnak a könyvtárban, vagy be sem jönnek, csak valamelyik elektronikus felületünkön keresztül kérnek segítséget az irodalomgyüjtésben, és általában a dolgozatírásban. Ilyenkor meg szoktuk kérdezni, hogy eddig milyen forrásokban keresett, milyen módszerrel, és többnyire az derül ki, hogy a Google-t használta. A tananyagot készen kapta, sohasem kellett egy-egy olvasásra ajánlott cikket, tanulmányt saját magának megkeresnie.

A könyvtár minden hallgatói csoportot igyekszik támogatni. Tanrenden kívüli képzéseket, tréningeket kínálunk a saját szakértelmünk által behatárolt területen, ezekre épülöen pedig csoportos vagy akár egyéni konzultációkon kaphatnak konkrét eligazitást egy-egy kérdésben. A cél az, hogy segítsük a hallgatókat az információs források közötti eligazodásban, az információ tudatos és etikus felhasználásában, az önálló munkában. Nem helyettük akarjuk összegyüjteni például a dolgozathoz szükséges irodalmat, hanem olyan készségek (szándékosan nem a skill kifejezést használom) megszerzéséhez kívánjuk őket hozzásegíteni, amelyekre a munkájuk során nagy szükségük lesz. Ebben természetesen együttmüködünk az oktatókkal. Minél szélesebb körüvé válik az oktatókkal kialakított együttmüködés, annál több hallgatót érhetünk el ezekkel a szolgáltatásainkkal.

Trautmann László: A könyvtár hogyan tudja segíteni az egyetem oktatási és nevelési programjának megvalósítását? Van-e különbség ebből a szempontból a különböző oktatási szintek, azaz az alapszak, a mesterszak, a doktori képzés, illetve a továbbképzések között? 
Nagy Zsuzsanna: A kérdés első felére az előbbiekben, úgy gondolom, válaszoltam. Talán annyi kiegészitést tennék, hogy a napi könyvtári munka, vagyis az, hogy a könyvtári szolgáltató ponton mindig jelen vannak képzett könyvtárosok, akik legjobb tudásuk szerint, készségesen válaszolnak az olvasói kérdésekre, segítenek hozzáférni a feladott tananyaghoz, és ezer apró dologgal segítik a hallgatókat, másról sem szól, mint a hallgatók támogatásáról.

Ne feledkezzünk meg a könyvtárról mint tanulási térről. Erre változatlanul nagy az igény, mind a csendes olvasóteremre, mind a közös tanulás helyszínéül szolgáló konzultációs szobákra és közös terekre. Sajnos a tréningjeink, képzési szolgáltatásunk számára most nincs megfelelő helyszín, de reméljük, hogy ezen sikerül majd változtatnunk.

A különböző képzési szintek között természetesen vannak különbségek. Az alapszakosoknak mi is alapvető könyvtárhasználati ismeretek nyújtunk. A mesterszakosoknak már jóval differenciáltabb készségeket próbálunk átadni. Mindkét célcsoport esetében fontos a plágium elkerülésére való módszeres felkészítés. A legsokrétűbb, leginkább kidolgozott, már az akadémiai készségeket is magában foglaló programot a doktori képzésben résztvevőknek kínáljuk. Ezekbe a programokba igyekszünk beépíteni a tudományos kommunikáció mélyreható változásaiból következő tudnivalókat, mint például a nyílt hozzáférés és a nyitott tudomány feltételrendszerét, a tudományos teljesítmények értékelésében utat törő új szemléletmódot, a digitális kutatási ökoszisztémából eredő módszertani változásokat.

\section{Trautmann László: Milyen az Egyetemi Könyvtár együttmüködése a Budapesten müködö többi szakkönyvtárral? Mennyire versenyeznek ezek az intézmények, és mennyiben egészítik ki egymást? Hogyan lehetne javítani ezt az együttmüködést?}

Nagy Zsuzsanna: A legjobb és legszorosabb együttmüködésröl az egyetemi könyvtárak esetében tudok beszámolni. Köszönhető ez részben annak is, hogy - néhány kivételtől eltekintve - az összes egyetemi könyvtár vezetői tagjai egy jól működő szakmai szervezetnek, az Egyetemi Könyvtárigazgatók Kollégiumának. Ennek a szervezetnek a keretében napi szinten kommunikálunk, segítjük egymást a közös vagy hasonló problémák megoldásában, megosztjuk egymással a tapasztalatainkat, a jó gyakorlatokat. Közösen dolgoztuk ki a felsőoktatási könyvtárak stratégiai fejlesztési irányait, amit el is juttattunk mind a felsőoktatást, mind a könyvtári területet irányító minisztérium illetékes vezetőinek. Bízunk benne, hogy erre alapozva lehetőséget kapunk olyan összehangolt közös fejlesztésekre, amelyek mind a felsőoktatás teljesítményét, mind a digitális világhoz alkalmazkodó könyvtári munka feltételeit javítani fogják. Emellett igen jó az együttmüködésünk a szakkönyvtárakkal is, kiemelném az MTA Könyvtár és Információs Központot, az Országgyülési Könyvtárat és a KSH Könyvtárát. Bizonyos nagy projektekben velük együttmüködve remélünk elörelépést.

Valódi, vagyis az erőforrásokért folyó versenyről az egyetemi és a szakkönyvtárak esetében nem beszélhetünk. A verseny ebben az összefüggésben arra korlátozódik, hogy természetes módon mindannyian szeretnénk a legkiválóbb, leginnovatívabb szolgáltatásokat nyújtani. Azt hiszem, hogy ebben a versenyben a mi könyvtárunk nem áll rosszul, de ez nem jelenti azt, hogy ne kellene folyamatosan nem csupán a színvonal fenntartására, de egyre jobb szolgáltatások nyúitására törekednünk. 